\title{
Tipe penggunaan lahan memengaruhi keanekaragaman dan komposisi hymenopteran parasitoid di Jambi
}

\author{
Land use types affect the diversity and composition of parasitoid \\ hymenopterans in Jambi
}

\author{
Muhammad Iqbal Tawakkal ${ }^{{ }^{*}}$, Akhmad Rizali ${ }^{2}$, Anik Larasati ${ }^{1}$, Adha Sari ${ }^{1}$, \\ Purnama Hidayat ${ }^{1}$, Damayanti Buchori ${ }^{1}$ \\ ${ }^{1}$ Departemen Proteksi Tanaman, Fakultas Pertanian, Institut Pertanian Bogor \\ Jalan Kamper, Kampus IPB Dramaga, Bogor 16680 \\ ${ }^{2}$ Jurusan Hama dan Penyakit Tumbuhan, Fakultas Pertanian, Universitas Brawijaya \\ Jalan Veteran, Malang 65145
}

(diterima April 2018, disetujui Desember 2018)

\begin{abstract}
ABSTRAK
Hymenoptera merupakan salah satu dari empat ordo serangga terbesar di dunia yang salah satu perannya adalah sebagai musuh alami (parasitoid, predator). Konversi lahan dapat memengaruhi keanekaragaman dan komposisi hymenopteran parasitoid dan peran ekologisnya. Penelitian ini bertujuan untuk memelajari pengaruh tipe penggunaan lahan terhadap keanekaragaman dan komposisi dari hymenopteran parasitoid di Jambi. Penelitian diakukan pada berbagai tipe penggunaan lahan di lanskap Hutan Harapan dan Taman Nasional Bukit Duabelas (TNBD), Provinsi Jambi meliputi hutan, hutan karet, perkebunan kelapa sawit, dan perkebunan karet. Pengambilan sampel serangga dilakukan dari bulan Maret sampai September 2013, dengan teknik pengasapan (fogging). Sebanyak 14.258 individu hymenopteran parasitoid yang terdiri atas 30 famili diperoleh dari seluruh lokasi penelitian. Famili Encyrtidae, Bracondae, Aphelinidae, Eulophidae, Scelionidae, Ceraphronidae, dan Platigasteridae merupakan famili yang ditemukan dengan kelimpahan tinggi. Tipe penggunaan lahan kelapa sawit ditemukan memiliki komposisi parasitoid berbeda dibandingkan dengan tipe penggunaan lahan lainnya, sedangkan tipe penggunaan lahan hutan dan hutan karet memiliki komposisi spesies yang tinggi. Hasil penelitian ini menunjukkan bahwa tipe penggunaan lahan mempengaruhi keanekaragaman dan komposisi spesies hymenopteran parasitoid.
\end{abstract}

Kata kunci: hutan hujan tropis, keanekaragaman hayati, lanskap

\begin{abstract}
Hymenoptera is one of the four largest insect orders in the world, one of which is its role as a natural enemy (parasitoids, predators). Land conversion can affect the diversity and composition of the parasitoid Hymenopteran and its ecological role. This study aims to examine the effect of land use types on the diversity and composition of hymenopterans parasitoid in Jambi. The study was conducted on various types of land use in the Harapan Forest landscape and Bukit Duabelas National Park (TNBD), Jambi Province including forests, rubber forests, oil palm plantations, and rubber plantations. Insect sampling was conducted from March to September 2013, using fogging techniques. A total of 14,258 hymenopteran parasitoid individuals consisting of 30 families were obtained from all study sites. Encyrtidae, Braconidae, Aphelinidae, Eulophidae, Scelionidae, Ceraphronidae, and Platigasteridae families are found in high abundance. Oil palm land use types are found to have different parasitoid compositions compared to other land use types, while forest and rubber forest land use types have high species composition. The results of this study indicate that the type of land use affects the diversity and composition of hymenopteran parasitoid species.
\end{abstract}

Key words: biodiversity, landscapes, tropical rainforests

*Penulis korespondensi: Muhammad Iqbal Tawakkal. Departemen Proteksi Tanaman, Fakultas Pertanian, Institut Pertanian Bogor Jalan Kamper, Kampus IPB Dramaga, Bogor 16680. Tel: 0251-8629364, Faks: 0251-8629362, Email: Itawakkal35@ymail.com 


\section{PENDAHULUAN}

Hymenoptera merupakan salah satu dari empat ordo serangga terbesar di dunia, di bawah Coleoptera, Lepidoptera, dan Diptera, yang mempunyai spesies lebih dari 100.000 spesies (Goulet \& Huber 1993). Terdapat lebih dari 153.000 spesies yang telah diidentifikasi terdiri atas 132 famili dan 8.432 genus (Aguiar et al. 2013). Namun, menurut Grissell (1999) jika semua spesies yang belum diidentifikasi turut diperhitungkan maka Hymenoptera merupakan ordo yang memiliki keanekaragaman spesies paling banyak daripada Ordo Coleoptera dan ordo lainnya. Hymenoptera dikelompokkan menjadi parasitoid, predator, penyerbuk, dan fitofag yang memiliki peran penting dalam ekosistem. Parasitoid dapat digunakan untuk mengontrol populasi serangga fitofag (Tscharntke et al. 2007) sehingga dapat digunakan sebagai agens pengendali hayati yang efektif untuk mengendalikan serangga hama (Bale et al. 2008; Brodeur \& Boivin 2004).

Studi tentang hymenopteran parasitoid di daerah hutan hujan tropis di Indonesia belum banyak dilakukan setelah penelitian dari Noyes (1989). Hasil penelitiannya menyebutkan bahwa keanekaragaman hymenopteran parasitoid yang didapatkan lebih tinggi pada daerah tropis (Sulawesi) dibandingkan dengan daerah yang beriklim subtropis, terutama pada Superfamili Chalcidoidea, namun untuk Superfamili Ichneumonoidea keanekaragamannya masih lebih tinggi pada daerah subtropis (Britain). Sebanyak 3.625 morfospesies hymenopteran parasitoid yang berasal 27 famili berhasil diperoleh pada penelitian di Sulawesi Utara. Famili yang memiliki kekayaan spesies terbanyak adalah Famili Braconidae dan Ichneumonidae dengan total kekayaan spesies sebanyak 431 dan 420, tetapi masih jauh lebih rendah jika dibandingkan dengan kekayaan spesies kedua famili tersebut pada hasil yang didapatkan dari Inggris yang berjumlah sebanyak 1.163 dan 2.029 (Noyes 1989). Pada penelitian Atmowidi (2000) di Taman Nasional Gunung Halimun kekayaan spesies kedua famili tersebut sebanyak 27 dan 29 morfospesies. Pola kekayaan spesies parasitoid Famili Ichneumonidae pada daerah tropis masih belum dapat dideskripsikan karena keanekaragamannya yang tinggi (Veijalainen et al. 2012).

Konversi lahan hutan hujan tropis menjadi lahan lainnya, seperti perkebunan serta agroforestri yang monokultur dapat memengaruhi kekayanan serangga di dalamnya khususnya Hymenoptera. Gangguan dari konversi lahan hutan tersebut secara signifikan dapat mengubah komposisi asli dari spesies serangga dan peran ekologisnya di dalam ekosistem (Cardoso et al. 2011). Alih fungsi penggunaan lahan tidak hanya mempengaruhi spesies parasitoid Famili Braconidae, tetapi juga memiliki dampak negatif pada serangga herbivora. (Ruiz-Guerra et al. 2015). Contoh lain yang menunjukkan bahwa konversi lahan dapat memengaruhi keanekaragaman di dalamnya dapat dilihat pada penelitian Rubiana (2015) yang menjelaskan bahwa transformasi habitat memiliki peranan penting dalam pembentukan struktur komunitas semut (Hymenoptera: Formicidae) yang dapat menyebabkan kerugian tidak langsung pada keanekaragaman hayati lainnya karena komunitas tersebut hanya akan berisi semut tramp dan semut invasif.

Struktur lanskap juga dapat mempengaruhi keanekaragaman hymenopteran parasitoid, seperti pada penelitian Lizmah (2018) yang menunjukkan bahwa keanekaragaman dan kelimpahan hymenopteran parasitoid lebih tinggi pada lanskap pertanian yang lebih kompleks. Pada lanskap kompleks ditemukan 233 spesies dan 1.382 individu dari 28 famili, sedangkan pada lanskap sederhana ditemukan 23 famili dari 157 spesies, dan 695 individu. Ulina (2017) juga melaporkan bahwa keanekaragaman hymenopteran parasitoid pada lahan mentimun terendah ditemukan di lanskap sederhana dengan jumlah 67 spesies dan tertinggi di lanskap sangat kompleks sebanyak 99 spesies. Selain itu, kompleksitas lanskap juga memengaruhi tingkat parasitisasi oleh parasitoid.

Penelitian ini bertujuan untuk memelajari pengaruh tipe penggunaan lahan, yaitu hutan, hutan karet, perkebunan kelapa sawit, dan perkebunanan karet terhadap kekayaan spesies, kelimpahan, dan komposisi hymenopteran parasitoid pada dua lanskap yang berbeda. Dari penelitian ini diharapkan dapat diperoleh informasi keanekaragaman hymenopteran pada lahan transformasi dari hutan menjadi perkebunan 
sehingga dapat mengurangi dampak negatif transformasi lahan di kawasan hutan hujan tropis di Indonesia terhadap lingkungan, khususnya pengaruh terhadap serangga serta dapat menjaga kelestarian habitatnya.

\section{BAHAN DAN METODE}

\section{Lokasi penelitian}

Pengambilan sampel parasitoid dilakukan dari bulan Mei-Oktober 2013, sedangkan proses identifikasi dilakukan dari Desember 2013-Juni 2017. Pengambilan sampel dilakukan pada dua lanskap hutan hujan tropis, yaitu lanskap Taman Nasional Bukit Duabelas (TNBD) dan Hutan Harapan, Jambi (Gambar 1). Kawasan TNBD berada dalam tiga wilayah kabupaten, yaitu Sarolangun, Bungo Tebo, dan Batanghari. Lanskap Hutan Harapan merupakan hutan hujan tropis dataran rendah yang menjadi kawasan restorasi ekosistem, terletak di Kabupaten Batang Hari. Identifikasi hymenopteran parasitoid dilakukan di Laboratorium Pengendalian Hayati, Departemen Proteksi Tanaman, Fakultas Pertanian, Institut Pertanian Bogor.

\section{Plot pengamatan}

Plot pengambilan sampel yang digunakan dalam penelitian ini adalah plot inti yang digunakan dalam poyek kerjasama penelitian CRC
990 - EFForTS (Drescher et al. 2016). Sampel dikoleksi dari empat tipe penggunaan lahan, yaitu hutan sekunder, hutan karet, perkebunan karet, dan perkebunan kelapa sawit yang terdapat di dua lanskap berbeda (Hutan Harapan dan Taman Nasional Bukit Duabelas). Dari kedua lanskap ini, ditentukan empat tipe penggunaan lahan (Tabel 1) yang dideskripsikan sebagai berikut: (a) hutan, yaitu hutan alam dengan kondisi masih utuh dan belum dieksplotasi oleh manusia (berumur lebih dari 20 tahun); (b) hutan karet, yaitu hutan dengan sistem agroforestri oleh tanaman karet yang tumbuh secara alami setelah terjadinya kerusakan pada hutan pertama; (c) perkebunan karet, yaitu perkebunan dengan sistem monokultur tanaman karet yang dibuka khusus untuk keperluan masyarakat adat; (d) perkebunan kelapa sawit, yaitu perkebunan dengan sistem monokultur tanaman kelapa sawit yang dibuka khusus untuk keperluan masyarakat. Setiap tipe penggunaan lahan terdiri atas empat plot pengamatan dengan tiga subplot berupa kanopi pohon target. Berdasarkan hal ini, jumlah subplot yang diamati berjumlah 48 subplot untuk masing-masing lanskap. Subplot tersebut digunakan sebagai titik pengambilan sampel. Masing-masing plot pengamatan memiliki ukuran $50 \mathrm{~m} \times 50 \mathrm{~m}$.

\section{Pengambilan sampel artropoda}

Pengambilan sampel dilakukan dengan menggunakan metode pengasapan (fogging).

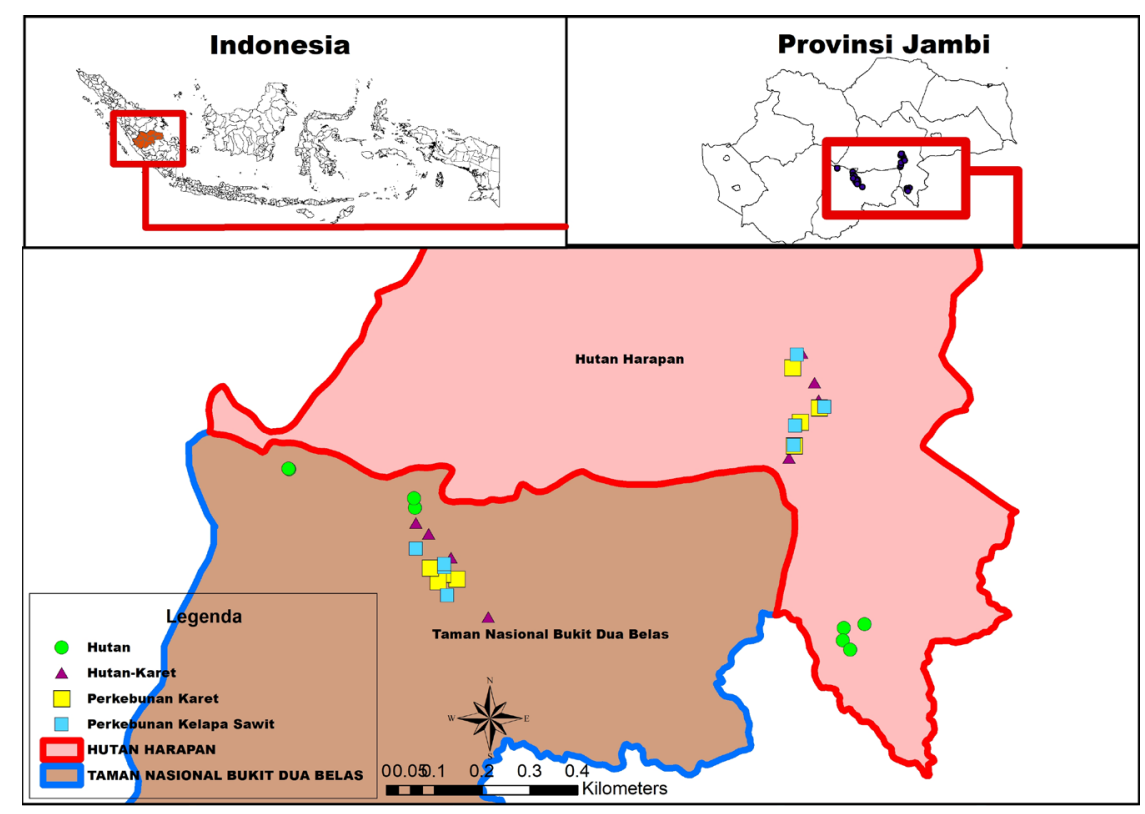

Gambar 1. Peta lokasi penelitian di Provinsi Jambi. 
Tabel 1. Karakteristik empat tipe penggunaan lahan di lanskap Hutan Harapan dan Taman Nasional Bukit Duabelas, Jambi

\begin{tabular}{lccccc}
\hline Plot penelitian & Kode & $\begin{array}{c}\text { Umur } \\
\text { (tahun })\end{array}$ & $\begin{array}{c}\text { Ketinggian } \\
\text { (m dpl) }\end{array}$ & Kondisi* & Kanopi* \\
\hline TNBD & & & & & \\
$\quad$ Hutan & $>20$ & $77-87$ & I, II, IV & T \\
Hutan karet & BJ & $>15$ & $40-89$ & I, II, V & T \\
Perkebunan karet & BR & $5-10$ & $51-90$ & III, VI & B \\
$\quad$ Perkebunan kelapa sawit & BO & $5-7$ & $34-84$ & II, VI & S \\
Hutan Harapan & & & & & \\
Hutan & HF & $>20$ & $62-74$ & I, II, IV & T \\
Hutan karet & HJ & $>15$ & $51-95$ & I, II, V & T \\
Perkebunan karet & HR & $5-10$ & $59-90$ & III, VI & B \\
Perkebunan kelapa sawit & HO & $5-7$ & $48-81$ & II, VI & S \\
\hline
\end{tabular}

*Menunjukkan kondisi I: ditemukan pohon berkayu, tanaman obat, dan rotan; II: ditemukan tanaman penutup tanah; III: tidak ditemukan jenis pohon lain dan tanaman penutup tanah; IV: ditemukan pohon jenis lain dengan diameter $>30 \mathrm{~cm}$; V: sistem pertanian ekstensif; VI: sistem pertanian intensif;

** Menunjukkan kanopi T: kanopi tertutup >70\%; B: kanopi terbuka <50\%; S: kanopi sedang 50-70\%.

Larutan yang digunakan untuk pengasapan adalah insektisida berbahan aktif piretroit sebanyak $50 \mathrm{ml}$ yang dicampur dengan minyak putih sebanyak 4,5 1 untuk mengurangi efek toksisitas insektisida sehingga serangga yang tidak masuk ke peranggkap dapat hidup kembali atau hanya menyebabkan pingsan. Pengasapan dilakukan pada pagi hari sekitar pukul 06.00 waktu setempat, dengan mengarahkan asap putih mengandung insektisida ke arah kanopi pohon target selama 20 menit. Sebanyak 16 wadah penampungan berbentuk limas yang berukuran $1 \mathrm{~m} \mathrm{x} 1 \mathrm{~m}$, dipasang pada bagian bawah kanopi pohon target. Ujung wadah penampungan dipasang botol koleksi yang berisi etanol (EtOH) 70\%. Dua jam setelah pengasapan, arthropoda yang jatuh ke wadah penampungan dimasukkan ke dalam botol koleksi dan diberi label sesuai dengan plot dan subplot serta tanggal pengambilan sampel. Identifikasi dilakukan di laboratorium hingga tingkat morfospesies.

\section{Identifikasi hymenopteran parasitoid}

Sampel arthropoda yang telah dikumpulkan disortir berdasarkan ordo, kemudian dipilih Ordo Hymenoptera. Setelah itu, hanya dipilih enam Famili hymenopteran parasitoid untuk diidentifikasi lebih lanjut ke tingkat morfospesies, yaitu Famili Braconidae, Ceraphronidae,
Encyrtidae, Eulophidae, Platygasteridae, dan Scelionidae. Identifikasi sampel hymenopteran menggunakan mikroskop binokuler Stemi 2000 dan buku Hymenoptera of The World: An Identification Guide to Families (Goulet \& Huber 1993).

\section{Analisis data}

Data morfospesies hymenopteran parasitoid dari enam famili yang dipilih ditabulasikan ke dalam pivot table dengan menggunakan perangkat lunak Microsoft Excel 2013. Analisis nilai abundance coverage-based estimator (ACE) digunakan untuk menduga kelimpahan hymenopteran parasitoid tiap famili yang terdapat pada setiap tipe penggunaan lahan. Nilai ACE diperoleh melalui perangkat lunak Estimate $\mathrm{S}$ versi 9.1.0 (Colwell 1997). Kelimpahan dan kekayaan spesies hymenopteran parasitoid pada berbagai tipe penggunaan lahan dianalisis menggunakan ANOVA dan ditampilkan dalam box-plot. Komposisi hymenopteran parasitoid dianalisis menggunakan analisis kesamaan (ANOSIM) berdasarkan indeks ketidakmiripan Bray-Curtis yang ditampilkan pada grafik non metric multi dimensional scalling (NMDS). Data diolah menggunakan perangkat lunak $R$ statistic versi 3.4.1 dengan package vegan (R-Development 2014). 
HASIL

\section{Estimasi kekayaan hymenopteran parasitoid}

Jumlah keseluruhan morfospesies hymenopteran parasitoid diprediksi menggunakan analisis penduga ACE dan kurva akumulasi spesies. Nilai ACE yang didapatkan pada setiap tipe penggunaan lahan berbeda-beda. Nilai ACE tertinggi didapatkan pada tipe penggunaan lahan hutan sebesar 978 di lanskap TNDB dan nilai terendah didapatkan pada tipe penggunaan lahan perkebunan kelapa sawit sebesar 354 di lanskap Hutan Harapan (Tabel 2). Persentase jumlah morfospesies yang berhasil dikumpulkan dari ke empat tipe penggunaan lahan berkisar antara 44,90-70,14\%. Nilai tersebut merupakan hasil pembagian antara nilai kekayaan hymenopteran parasitoid dan nilai kekayaan prediksinya. Masih rendahnya nilai persentase pada keempat tipe penggunaan lahan tersebut dapat diartikan bahwa masih banyak morfospesies yang belum berhasil dikumpulkan. Hasil nilai observasi dan prediksi ACE ditampilkan pada kurva akumulasi spesies yang menunjukkan bahwa kekayaan spesies parasitoid pada lanskap TNDB lebih tinggi sebesar 922 morfospesies jika dibandingkan dengan lanskap Hutan Harapan sebesar 703 morfospesies (Gambar 2).

\section{Kenekaragaman hymenopteran parasitoid}

Sebanyak 14.258 individu hymenopteran parasitoid yang terdiri atas 30 famili telah berhasil dikumpulkan pada penelitian ini (Tabel 3). Pada lanskap TNBD ditemukan sebanyak 9.301 individu yang terdiri atas 30 famili dengan kelimpahan parasitoid tertinggi terdapat tipe penggunaan lahan hutan sebesar 4.452 individu, sedangkan pada lanskap Hutan Harapan ditemukan sebanyak 4.957 individu yang terdiri atas 28 famili dengan kelimpahan tertinggi terdapat pada tipe penggunaan lahan hutan karet sebesar 1.677, sedangkan kelimpahan individu hymenopteran parasitoid terendah terdapat pada tipe penggudaan lahan kelapa sawit di kedua lanskap.

Masing-masing tipe penggunaan lahan pada lanskap TNBD memiliki jumlah kelimpahan parasasitoid yang lebih tinggi jika dibandingkan dengan lanskap Hutan Harapan. Sebagai contoh, pada tipe penggunaan lahan hutan di lanskap TNBD didapatkan sebanyak 4.452 individu parasitoid, sedangkan pada tipe penggunaan lahan hutan di lanskap Hutan Harapan hanya didapatkan sebanyak 1.663 individu parasitoid. Aphelinidae, Bracondae, Ceraphronidae, Encyrtidae, Eulophidae, Platigasteridae, dan Scelionidae merupakan famili dengan kelimpaham tertinggi yang mendominasi pada kedua lanskap (Gambar 3).

\section{Pengaruh tipe penggunaan lahan terhadap keanekaragaman hymenopteran parasitoid}

Keanekaragaman dari enam famili hymenopteran parasitoid pada TNBDB dan Hutan Harapan dilihat berdasarkan perbedaan lanskap dan tipe penggunaan lahan. Berdasarkan

Tabel 2. Estimasi kekayaan enam famili hymenopteran parasitoid pada empat tipe penggunaan lahan di lanskap Hutan Harapan dan TNBD

\begin{tabular}{lccc}
\hline \multirow{2}{*}{ Lokasi penelitian } & \multicolumn{3}{c}{ Total spesies } \\
\cline { 2 - 4 } Hutan Harapan & Obs & ACE & Sp (\%) \\
$\quad$ Hutan & 413 & 725 & 56,96 \\
Hutan karet & 377 & 643 & 58,63 \\
Perkebunan kelapa sawit & 178 & 354 & 50,28 \\
Perkebunan karet & 208 & 480 & 43,33 \\
TNBD & & & \\
Hutan & 686 & 978 & 70,14 \\
Hutan karet & 499 & 809 & 61,68 \\
Perkebunan kelapa sawit & 254 & 538 & 47,21 \\
Perkebunan karet & 247 & 550 & 44,90 \\
\hline
\end{tabular}

Obs: Jumlah mofospesies hymenopteran parasitoid yang ditemukan; ACE: abundance coverage-based estimator, prediksi kelimpahan morfospesies hymenopteran parasitoid; Sp (\%): persentase kelimpahan morfospesies hymenopteran parasitoid yang berhasil ditemukan. 


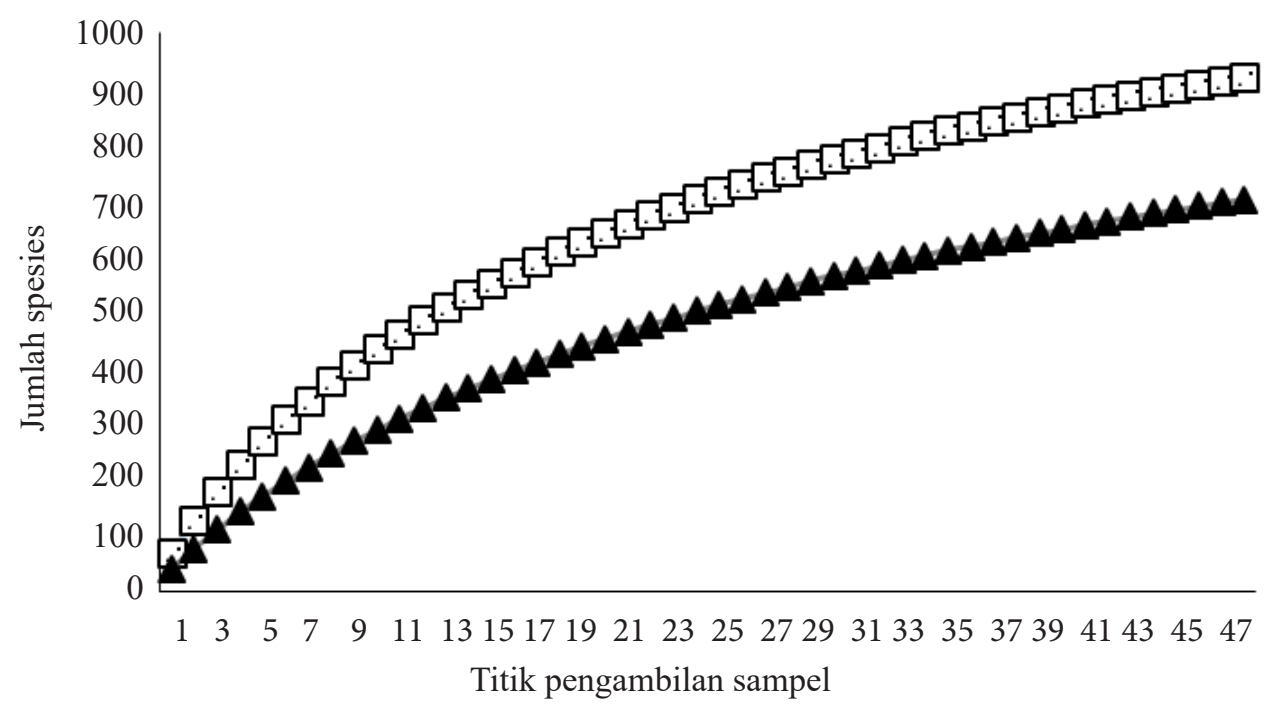

Gambar 2. Kurva akumulasi spesies hymenopteran parasitoid pada lanskap $\longrightarrow$ : Hutan Harapan dan ․: Taman Nasional Bukit Duabelas.

hasil identifikasi lebih lanjut untuk enam famili hymenopteran parasitoid didapatkan hasil Famili Braconide terdiri atas 2.757 individu dan 309 morfospesies, Ceraphronidae terdiri atas 911 dan 157 morfospesies, Encyrtidae 3.075 dan 170 morfospesies, Eulophidae terdiri atas 1.371 individu dan 162 morfospesies, Platigasteridae terdiri atas 862 individu dan 189 morfospesies, serta Scelionide yang terdiri atas 1.320 dan 194 morfospesies. Berdasarkan hasil uji ANOVA perbedaan tipe pengguaan lahan pada kedua lanskap mempengaruhi keanekaragaman keenam famili hymenopteran parasitoid, yaitu Famili Braconidae $(\mathrm{F}=19,91 ; \mathrm{P}<0,001)$, Ceraphronidae $(\mathrm{F}=11,58 ; \mathrm{P}<0,001)$, Encyrtidae $(\mathrm{F}=5,872 ; \mathrm{P}$ $=0,00047)$, Eulophidae $(\mathrm{F}=31,62 ; \mathrm{P}<0,0010)$ Platygasteridae $(\mathrm{F}=14,74 ; \mathrm{P}<0,001)$ dan Scelionidae $(\mathrm{F}=5,302, \mathrm{P}=0,000922)$.

Pola kekayaan spesies hymenopteran pada masing-masing tipe penggunaan lahan hampir sama, yaitu keanekaragaman tertinggi berada pada tipe penggunaan lahan hutan, kemudian hutan karet, kelapa sawit dan yang paling rendah berada pada tipe penggunaan lahan perkebunan karet (Gambar 4). Namun, untuk Famili Braconidae dan Ceraphronidae kekayaan spesies di lahan perkebunan kelapa sawit lebih rendah daripada lahan perkebunan karet. Pada lanskap Hutan Harapan untuk Famili Scelionide dan Encyrtidae kekayaan spesies tertinggi terdapat pada tipe penggunaan lahan hutan karet, sedangkan kekayaan spesies hymenopteran parasitoid terendah ditemukan pada tipe penggunaan lahan kelapa sawit, kecuali untuk Famili Eulophidae dan Scelionidae yang kekayaan spesies terendahnya terdapat pada tipe penggunaan lahan karet.

\section{Perbedaan komposisi hymenopteran parasitoid pada empat tipe penggunaan lahan}

Hasil analisis NMDS menunjukan bahwa komposisi hymenopteran parasitoid pada keempat tipe penggunaan lahan berbeda. Lanskap TNDB (ANOSIM $\mathrm{R}=0,767 ; \mathrm{P}=0,001$ ) dan Hutan Harapan (ANOSIM R $=0,538 ; \mathrm{P}=0,001)($ Gambar 5). Di lanskap TNDB komposisi hymenopteran parasitoid sangat berbeda karena jarak antartitik untuk masing-masing tipe penggunaan lahan saling berjauhan, kecuali pada tipe penggunaan lahan hutan dan hutan karet yang jarak titik masih berdekatan sehingga dapat dikatakan komposisi hymepoteran pada kedua tipe penggunaan lahan tersebut masih memiliki kemiripan yang dekat. Pada lanskap Hutan Harapan hanya lahan kelapa sawit yang memiliki titik yang jauh dan tidak bersinggungan dengan titik pada tipe penggunaan lahan lainnya sehingga komposisi hymenopteran pada masing-masing tipe penggunaan lahan masih memiliki kemiripan, terkecuali untuk tipe penggunaan lahan kelapa sawit. 
Tabel 3. Kelimpahan parasitoid pada empat tipe penggunaan lahan di lanskap Taman Nasional Bukit Duabelas dan Hutan Harapan

\begin{tabular}{|c|c|c|c|c|c|c|c|c|c|}
\hline \multirow[b]{2}{*}{$\begin{array}{l}\text { Super famili } \\
\text { Famili }\end{array}$} & \multicolumn{4}{|c|}{ Bukit Duabelas } & \multicolumn{4}{|c|}{ Hutan Harapan } & \multirow[b]{2}{*}{ Total } \\
\hline & Hutan & $\begin{array}{c}\text { Hutan } \\
\text { karet }\end{array}$ & $\begin{array}{l}\text { Perkebun- } \\
\text { an kelapa } \\
\text { sawit }\end{array}$ & $\begin{array}{l}\text { Perkebun- } \\
\text { an karet }\end{array}$ & Hutan & $\begin{array}{c}\text { Hutan } \\
\text { karet }\end{array}$ & $\begin{array}{l}\text { Perkebun- } \\
\text { an kelapa } \\
\text { sawit }\end{array}$ & $\begin{array}{l}\text { Perkebun- } \\
\text { an karet }\end{array}$ & \\
\hline \multicolumn{10}{|l|}{ Chalcidoidea } \\
\hline Agaonidae & 25 & 14 & 29 & 14 & 18 & 6 & 1 & 4 & 111 \\
\hline Aphelinidae & 879 & 515 & 350 & 202 & 259 & 302 & 76 & 89 & 2.672 \\
\hline Chalcididae & 0 & 0 & 0 & 4 & 0 & 1 & 0 & 1 & 6 \\
\hline Chalcidoidea & 19 & 3 & 3 & 7 & 6 & 0 & 0 & 2 & 40 \\
\hline Elasmidae & 25 & 20 & 5 & 6 & 3 & 14 & 0 & 1 & 74 \\
\hline Encyrtidae & 656 & 456 & 182 & 425 & 318 & 293 & 145 & 600 & 3.075 \\
\hline Eucharytidae & 0 & 0 & 2 & 0 & 1 & 0 & 0 & 0 & 3 \\
\hline Eulophidae & 602 & 227 & 114 & 87 & 145 & 117 & 49 & 30 & 1.371 \\
\hline Eupelmidae & 36 & 49 & 2 & 11 & 3 & 21 & 1 & 3 & 126 \\
\hline Eurytomidae & 13 & 28 & 6 & 7 & 35 & 5 & 2 & 2 & 98 \\
\hline Mymaridae & 106 & 38 & 8 & 7 & 16 & 15 & 1 & 5 & 196 \\
\hline Mymmaromatidae & 1 & 0 & 0 & 0 & 1 & 0 & 0 & 0 & 2 \\
\hline Pteromalidae & 77 & 60 & 23 & 47 & 18 & 22 & 8 & 15 & 270 \\
\hline Signiphoridae & 10 & 11 & 1 & 0 & 0 & 1 & 1 & 0 & 24 \\
\hline Torymidae & 11 & 6 & 5 & 10 & 4 & 3 & 8 & 1 & 48 \\
\hline Trichogrammatidae & 22 & 12 & 7 & 6 & 18 & 15 & 5 & 3 & 88 \\
\hline \multicolumn{10}{|l|}{ Ceraphronoidea } \\
\hline Ceraphronidae & 300 & 180 & 67 & 66 & 129 & 93 & 32 & 44 & 911 \\
\hline Megaspilidae & 10 & 2 & 3 & 2 & 0 & 0 & 1 & 1 & 19 \\
\hline \multicolumn{10}{|l|}{ Chrysidoidea } \\
\hline Bethylidae & 22 & 10 & 3 & 9 & 0 & 15 & 4 & 1 & 64 \\
\hline Diapriidae & 3 & 6 & 9 & 0 & 3 & 5 & 6 & 1 & 33 \\
\hline Dryniidae & 6 & 3 & 4 & 1 & 0 & 1 & 1 & 0 & 16 \\
\hline \multicolumn{10}{|l|}{ Cynipoidea } \\
\hline Cynipidae & 7 & 5 & 12 & 1 & 2 & 2 & 1 & 2 & 32 \\
\hline Eucoilidae & 0 & 1 & 0 & 0 & 0 & 0 & 0 & 0 & 1 \\
\hline \multicolumn{10}{|l|}{ Evanoidea } \\
\hline Evaniidae & 1 & 0 & 0 & 0 & 2 & 0 & 0 & 0 & 3 \\
\hline \multicolumn{10}{|l|}{ Ichneumonoidea } \\
\hline Braconidae & 931 & 547 & 72 & 116 & 454 & 360 & 105 & 172 & 2.757 \\
\hline Ichneumonidae & 4 & 11 & 5 & 9 & 2 & 2 & 0 & 2 & 35 \\
\hline \multicolumn{10}{|l|}{ Platygastroidea } \\
\hline Platygastridae & 347 & 154 & 46 & 31 & 121 & 120 & 22 & 21 & 862 \\
\hline Scelionidae & 338 & 232 & 129 & 104 & 105 & 264 & 88 & 60 & 1.320 \\
\hline \multicolumn{10}{|l|}{ Stephanoidea } \\
\hline Stephanidae & 1 & 0 & 0 & 0 & 0 & 0 & 0 & 0 & 1 \\
\hline Total & 4.452 & 2.590 & 1.087 & 1.172 & 1.663 & 1.677 & 557 & 1.060 & 14.258 \\
\hline
\end{tabular}



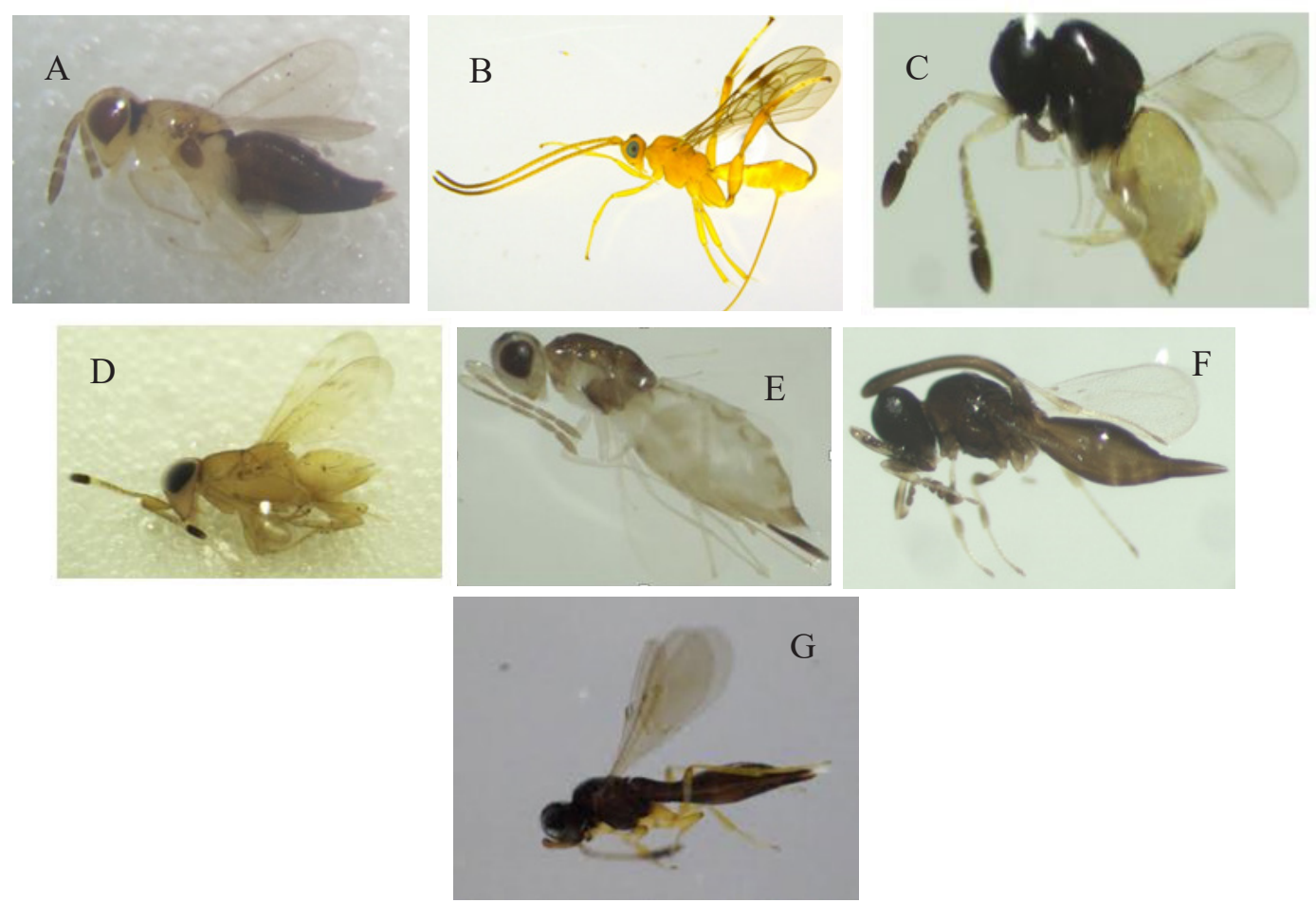

Gambar 3. Famili-famili hymenopteran parasitoid yang memiliki kelimpahan yang tinggi. A: Aphelinidae; B: Bracondae; C: Ceraphronidae; D: Encyrtidae; E: Eulophidae; F: Platigasteridae; G: Scelionidae.

\section{PEMBAHASAN}

Keanekaragaman hymenopteran parasitoid yang diperoleh melalui penelitian ini masih belum mendekati nilai prediksi ACE. Untuk mendekati nilai prediksi ACE yang sempurna mungkin dapat diperoleh apabila dilakukan sampling dengan jumlah unit pengambilan contoh yang banyak (Colwell \& Coddington 1994). Penentuan cukup tidaknya unit pengambilan sampel sesuai dengan nilai prediksi, sulit untuk dilakukan di lapangan. Pengambilan sampel diprediksi kelengkapannya di lapangan berdasarkan tidak ditemukannya lagi spesies yang baru dengan ditambahnya jumlah unit pengambilan sampel (Rizali 2006). Garis kurva akumulasi masih menunjukkan peningkatan di kedua lanskap yang artinya masih belum optimalnya pengambilan sampel pada kedua lanskap tersebut atau masih ada speseies yang belum berhasil dikumpulkan. Rubiana (2014) juga menyebutkan kurva akumulasi jumlah keseluruhan spesies yang dikumpulkan dari semua titik contoh tidak mencapai asimtot sampling yang berarti bahwa daftar spesies yang terdapat pada lahan tersebut belum lengkap.

Tinginya kelimpahan parasitoid pada tipe penggunaan lahan hutan dan hutan karet diduga memiliki hubungan dengan keanekaragaman tumbuhan pada tipe penggunaan lahan tersebut. Lahan hutan memiliki spesies tumbuhan lebih beragam jika dibandingkan dengan lahan perkebunan karet dan kelapa sawit (Drescher et al. 2016). Kekayaan spesies parasitoid berkaitan dengan kekayaan spesies tanaman ditempat pengambilan sampel dan ada kemungkinan bahwa korelasi positif tersebut disebabkan oleh peningkatan kompleksitas dan arsitektur tanaman pada suatu lahan (Haddad et al. 2001). Rott \& Godfray (2000) menyatakan bahwa komunitas parasitoid dipengaruhi oleh tumbuhan yang menjadi sumber makanan bagi serangga inang. Shaw (2006) juga menyebutkan bahwa jenis tumbuhan yang lebih beragam akan menyediakan lebih beragam serangga dan parasitoid spesialisnya. Hal ini karena lanskap TNBD merupakan lanskap yang masih alami atau lebih kompleks dengan masih banyaknya habitat alami pada lanskap tersebut, sedangkan lanskap Hutan Harapan merupakan lanskap yang banyak mengalami transformasi lahan dan restorasi yang mengakibatkan lanskap Hutan Harapan menjadi lebih sederhana sehingga keberadaan serangga pada lanskap tersebut juga ikut terganggu. Hasil ini sesuai dengan beberapa studi yang 

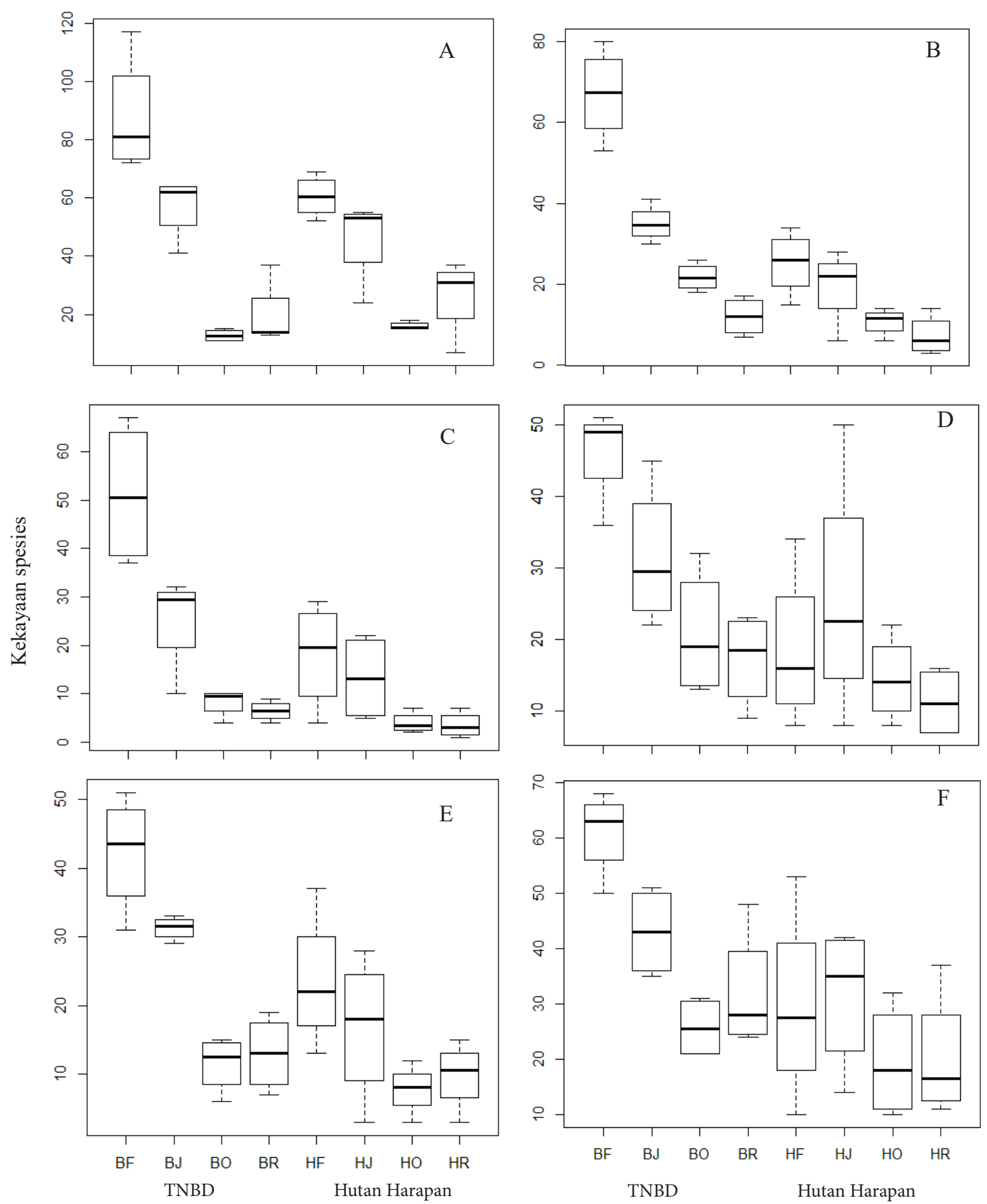

Tipe penggunaan lahan

Gambar 4. Kekayaan spesies enam famili hymenopteran parasitoid pada empat tipe penggunaan lahan di lanskap Taman Nasional Bukit Duabelas (TNBD) (kode untuk tipe penggunaan lahan BF: hutan; BJ: hutan karet; BR: perkebunan karet; HO: perkebunan kelapa sawit) dan Hutan Harapan (kode untuk tipe penggunaan lahan HF: hutan; HJ: hutan karet; HR: perkebunan karet; HO: perkebunan kelapa sawit). A: Braconide; B: Eulophida; C: Platgasteridae; D: Secionidae; E: Ceraphronidae; dan F: Encyrtidae. 

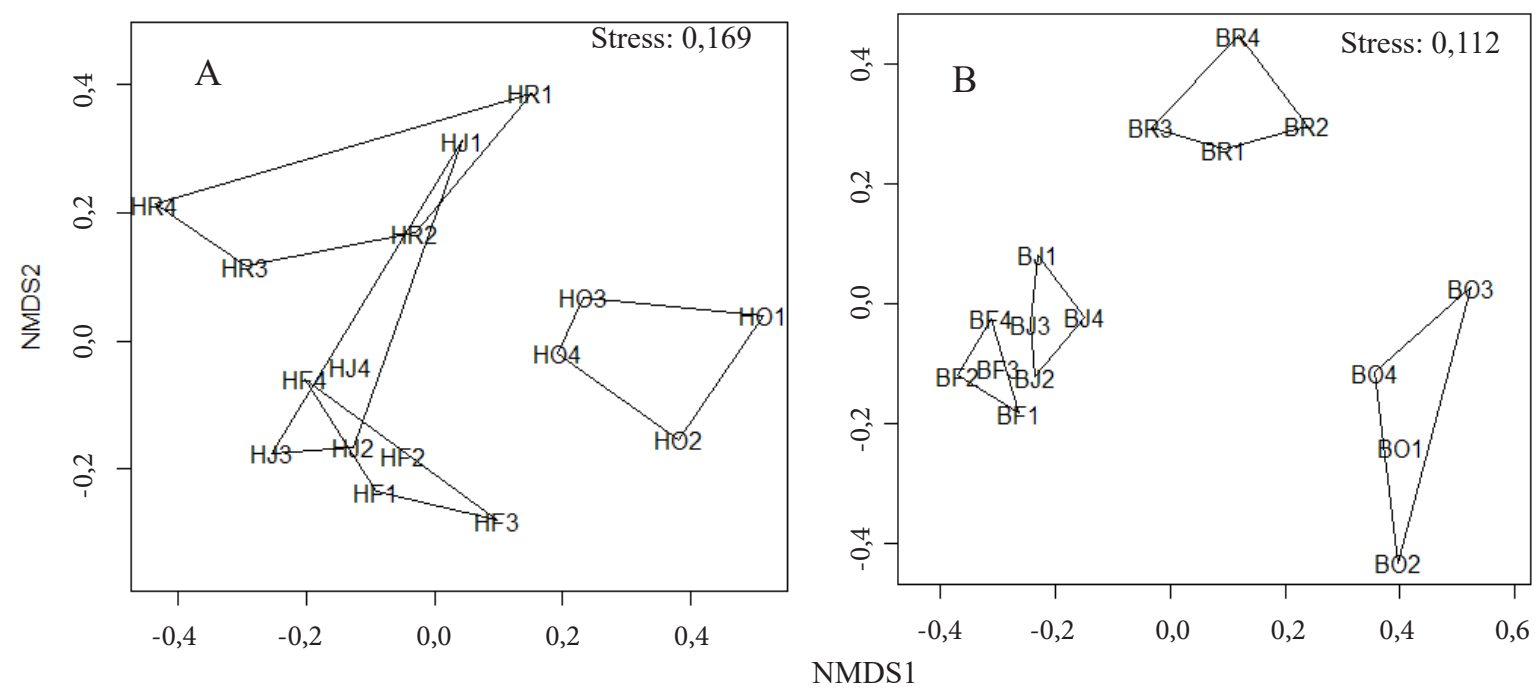

Gambar 5. NMDS komposisi hymenopteran parasitoid. A: lanskap Hutan Harapan (kode untuk tipe penggunaan lahan HF: hutan; HJ: hutan karet; HR: perkebunan karet; HO: perkebunan kelapa sawit); B: lanskap TNDB (kode untuk tipe penggunaan lahan BF: hutan; BJ: hutan karet; BR: perkebunan karet; HO: perkebunan kelapa sawit).

menunjukkan bahwa lanskap kompleks, yang memiliki lebih banyak habitat alami mampu meningkatkan kekayaan spesies dan kelimpahan musuh alami (Finke \& Snyder 2010; Holzschuh et al. 2010; Ulina 2017). Namun, kekayaan spesies dan kelimpahan musuh alami lebih rendah pada lanskap sederhana dibandingkan dengan lanskap kompleks. Hal ini disebabkan lanskap sederhana tidak mampu menyediakan kebutuhan musuh alami, seperti inang alternatif dan pakan bagi imagonya (Ge'neau et al. 2012).

Scelionide merupakan famili terbesar dari hymenopteran parasitoid yang anggota familinya menjadi parasitoid pada telur serangga dan telur laba-laba (Goulet \& Hubber 1993; Noyes 1989) sehingga berpotensi memiliki kisaran inang yang luas. Sebagai contoh, Scelionini hanya diketahui sebagai parasit telur belalang Acridid, Gryonini memarasit telur Heteroptera dan jarang ditemukan pada Lepidoptera, Mantibarini parasit pada telur Mantodea, Baeini parasit pada telur Araneae, dan Teleasinae parasit pada telur Coleoptera (Austin et al. 2005), sedangkan Famili Encyrtidae merupakan parasitoid dari kutu-kutuan dan sebagian memarasit telur serangga (Trjapitzin 2008; Noyes 1985). Rendahnya kekayaan spesies Famili Scelionidae dan Encyrtidae diduga karena pada lahan hutan pada lanskap Hutan Harapan telah mengalami restorasi sehingga mempengaruhi jenis tumbuhan dan serangga yang ada di dalamnya, terutama serangga inang bagi Famili Scelionidae dan Encyrtidae. Proses restorasi dapat menyebabkan hilanggnya sebagian serangga asli dan masuknya jenis serangga baru ke dalam habitat yang mengalami restorasi sehingga komunitas serangga pada habitat tersebut dapat bebeda dengan habitat asli yang belum mengalami restorasi. Hal ini juga disebutkan pada penelitian Gould et al. (2013) di kawasan hutan restorasi di Montane Hawaii yang menyebutkan bahwa 95\% sampel Ichneumonid yang ditemukan adalah bukan spesies asli dari habitat tersebut sehingga berdampak negatif pada beberapa sepesies lain karena hilanggnya spesies asli.

Kekayaan spesies dari Famili Braconidae dan Ceraphronidae pada tipe penggunaan lahan pekebunan kelapa sawit paling rendah. Hal ini, diduga karena pada tipe penggunaan lahan tersebut spesies tanaman lebih homogen sehingga kekayaan serangga herbivor atau serangga lain yang menjadi inang bagi kedua famili tersebut juga menurun jumlahnya. Sperber et al. (2004) dan Fraser et al. (2007) menyatakan bahwa kekayaan spesies pepohonan/semak dapat menjadi indikasi kekayaan spesies parasitoid, dengan peningkatan jumlah spesies pepohonan/semak juga dapat meningkatkan kekayaan spesies parasitoid. RuizGuerra et al. (2015) juga melaporkan bahwa jumlah spesies Braconidae lebih banyak ditemukan pada lahan hutan daripada lahan nonhutan. Selain itu, Famili Braconidae juga tergolong ke dalam jenis parasitoid yang spesifik inang atau spesialis (Wharton 1997) sehingga kehadirannya pada suatu ekosistem berkaitan erat dengan serangga 
inangnya yang berada di ekosistem. Pada lahan kelapa sawit, inang dari Braconidae didominasi oleh serangga pemakan daun dari Ordo Lepidoptera, seperti ulat api dan ulat kantung. Namun, berbeda dengan lahan hutan yang lebih heterogen dimana inang Braconidae tidak hanya didominasi dari Ordo Lepidoptera, namun ordo lainnya. Sebagai contoh di lahan hutan banyak terdapat pohon-pohon yang merupakan inang bagi kumbang penggerek batang. Serangga ini pada umumnya merupakan inang dari Braconidae Subfamili Doryctinae sehingga parasitoid ini akan lebih banyak ditemukan pada lahan yang lebih heterogen. Oleh karena itu, pada lahan kelapa sawit akan lebih sedikit ditemukan parasitoid ini karena serangga inangnya yang sedikit juga. Hal ini sesuai dengan hasil penelitian Maeto et al. (2009) yang menyatakan bahwa parasitoid penggerek batang kayu memiliki kekayaan spesies dan kelimpahan yang lebih tinggi pada lahan hutan dibandingkan dengan lahan lainnya.

\section{KESIMPULAN}

Keanekaragaman hymenopteran parasitoid tertinggi hingga terendah secara berurutan ditemukan pada tipe penggunaan lahan hutan, hutan karet, dan perkebunan kelapa sawit dan perkebunan karet. Tipe penggunaan lahan hutan pada lanskap TNDB memiliki kelimpahan parasitoid tertinggi, sedangkan tipe penggunaan lahan kelapa sawit pada lanskap Hutan Harapan memiliki kelimpahan yang paling rendah. Pada lanskap TNBD komposisi hymenopteran parasitoid menunjukkan perbedaan pada masing-masing tipe penggunan lahan, sedangkan pada lanskap Hutan Harapan hanya tipe penggunaan lahan perkebunan kelapa sawit yang menunjukkan perbedaan komposisi hymenopteran parasitoid dibandingkan dengan tipe penggunaan lahan lainnya.

\section{UCAPAN TERIMA KASIH}

Terima kasih kepada Prof. Stefan Scheu dan Jochen Drescher dari University of Göttingen yang telah memfasilitasi penelitian ini dalam proyek kerjasama penelitian CRC990-EFForTS (subgrup Z02).

\section{DAFTAR PUSTAKA}

Aguiar AP, Deans AR, Engel MS, Forshage M, Huber JH, Jennings JT, Johnson NF, Lelej AS, Longino JT, Lohrmann V, Miko I, Ohl M, Rasmussen C, Taeger A, Yu DSK. 2013. Order Hymenoptera. Zootaxa 3703:51-62. doi: https:// doi.org/10.11646/zootaxa.3703.1.12.

Atmowidi T. 2000. Keanekaragaman Morfospesies Hymenoptera Parasitoid dan Senyawa Antiherbivora di Taman Nasional Gunung Halimun, Jawa Barat. Tesis. Bogor: Institut Pertania Bogor. Austin AD, Johnson NF, Dowton M. 2005. Systematics, evolution, and biology of Scelionid and Platygastrid wasps. Annual Review of Entomology 50:553-582. doi: https://doi. org/10.1146/annurev.ento.50.071803.130500.

Bale JS, van Lenteren JC, Bigler F. 2008. Biological control and sustainable food production. Philosophical Transactions of the Royal Society B 363:761-776. doi: https://doi. org/10.1098/rstb.2007.2182.

Brodeur J, Boivin G. 2004. Functional ecology of immature parasitoids. Annual Review Entomology 49:27-49. doi: https://doi.org/10.1146/annurev. ento.49.061703.153618.

Cardoso P, Erwin TL, Borges PAV, New TR. 2011. The seven impediments in invertebrate conservation and how to overcome them. Biological Conservation 144:2647-2655. doi: https://doi.org/10.1016/j.biocon.2011.07.024.

Colwell RK, Coddington JA. 1994. Estimating terestrial biodiversity through extrapolation. Philosophical Transactions of the Royal Society $B$ 345:101-118. doi: https://doi. org/10.1098/rstb.1994.0091.

Colwell RK. 1997. EstimateS 5: Statistical estimation of spesies richness and shared spesies from samples. terhubung berkala. Tersedia di: http:// www.viceroy.eeb.uconn.edu.estimates. [diakses 16 Maret 2018].

Drescher J, Rembol K, Allen K, Beckäfer P, Buchori D, Clough Y, Faust H, Fauzi AM, Gunawan D, Hertel D et al. 2016. Ecological and sosioconomic functions across tropical land use system after rainforest conversion. Philosophical Transactions of the Royal Society B 371:20150275. doi: https://doi.org/10.1098/ rstb.2015.0275.

Finke DL, Snyder WE. 2010. Conserving the benefits of predator biodiversity. Biological. Conservation 143:2260-2269. doi: https://doi. org/10.1016/j.biocon.2010.03.022.

Fraser SEM, Dytham C, Mayhew PJ. 2007. Determinants of parasitoid abundance and 
diversity in woodland habitats. Journal of Applied Ecology 44:352-361. doi: https://doi. org/10.1111/j.1365-2664.2006.01266.x.

Ge'neau CE, Wa"ckers FL, Luka H, Daniela C, Balmer O. 2012. Selective flowers to enhance biological control of cabbage pests by parasitoids. Basic and Applied Ecology 13:85-93. doi: https://doi. org/10.1016/j.baae.2011.10.005.

Gould RK, Pejchar L, Bothwell SG, Brosi B, Wolny S, Mendenhall CD, Daily G. 2013. Forest restoration and parasitoid wasp communities in Montane Hawai'i. Plos One 8:e59356. doi: https://doi.org/10.1371/journal.pone.0059356.

Goulet H, Huber JT. 1993. Hymenoptera of the World: An Identification Guide to Families. Ottawa: Canada Communication Group Publishing.

Grissell EE. 1999. Hymenopteran diversity: Some alien notions. American Entomologist 45:235244. doi: https://doi.org/10.1093/ae/45.4.235.

Haddad NM, Tilman D, Haarstad J, Ritchie M, Knops J. 2001. Contrasting effects of plant species richness and composition on insect communities: a field experiment. The American Naturalist 158:17-35. doi: https://doi.org/10.1086/320866.

Holzschuh A, Steffan-Dewenter I, Tscharntke T. 2010. How do landscape composition and configuration, organic farming and fallow strips affect the diversity of bees, wasps and their parasitoids? Jounal of Animal Ecology 79:491-500. doi: https://doi.org/10.1111/j.13652656.2009.01642.x.

Lizmah SF. 2018. Kompleksitas lanskap pertanian dan pengaruhnya terhadap keanekaragaman Hymenoptera parasitika. Jurnal Entomologi Indonesia 15:124-133. doi: http://dx.doi. org/10.5994/jei.15.3.124.

Maeto K, Neordjito WA, SergeyA, FukuyamaK. 2009. Recovery of species diversity and composition of braconid parasitic wasps after reforestation of degraded grasslands in lowland East Kalimantan. Journal of Insect Conservation 13:245-257. doi: https://doi.org/10.1007/s10841-008-9164-3.

Noyes JS. 1989. The diversity of Hymenoptera in the tropics with special reference to parasitica in Sulawesi. Ecological Enfornology 14:197-207.

Noyes JS. 1985. Chalcidoids and biological control. Chalcid Forum 5:5-10 doi: https://doi. org/10.1111/j.1365-2311.1989.tb00770.x.

R-Development Core Team. 2014. R: A Language and Environment for Statistical Computing. $\mathrm{R}$ Foundation for Statistical Computing, Vienna.

Rizali A. 2006. Keanekaragaman Semut di Kepulauan Seribu, Indonesia. Tesis. Bogor: Institut Pertania Bogor.
Rott AS, Godfray HCJ. 2000. The structure of a leafminer-parasitoid community. Jounal of Animal Ecology 69:274-289. doi: https://doi. org/10.1046/j.1365-2656.2000.00390.x.

Rubiana R, Rizali A, Denmead LH, Alamsari W, Hidayat P, Hindayana D, Pudjianto, Clough Y, Tscharntke T, Buchori D. 2015. Agricultural land use alters species composition but not species richness of ant communities. Asian Myrmecology 7:73-85.

Ruiz-Guerra B, López-Acosta JC, Zaldivar-Riverón A, Velázquez-Rosas N. 2015. Braconidae (Hymenoptera: Ichneumonoidea) abundance and richness in four types of land use and preserved rain forest in southern Mexico. Revista Mexicana de Biodiversidad 86:164-171. doi: https://doi. org/10.7550/rmb.43865.

Shaw MR. 2006. Habitat considerations for parasitic wasps (Hymenoptera). Journal of Insect Conservation 10:117-127. doi: https://doi. org/10.1007/s10841-006-6288-1.

Sperber CF, Nakayama K, Valverde MJ, Neves FD. 2004. Tree species richness and density affect parasitoid diversity in cacao agroforestry. Basic and Applied Ecology 5:241-251. doi: https://doi. org/10.1016/j.baae.2004.04.001.

Trjapitzin VA. 2008. A review of Encyrtid wasps (Hymenoptera, Chalcidoidea, Encyrtidae) of Macaronesia. Entomological Review 88:218-232. doi: https://doi.org/10.1134/S0013873808020085.

Tscharntke T, Bommarco R, Clough Y, Crist TO, Kleijn D, Rand TA, Tylianakis JM, van Nouhuys S, Vidal S. 2007. Conservation biological control and enemy diversity on a landscape scale. Biological Control 43:294-309. doi: https://doi. org/10.1016/j.biocontrol.2007.08.006.

Ulina ES. 2017. Hubungan antara Struktur Lanskap Pertanian dengan Komunitas Lepidoptera dan Hymenoptera Parasitika. Disertasi. Bogor: Institut Pertania Bogor.

Veijalainen A, Wahlberg N, Broad GN, Erwin TL, Longino JT, Sääksjärvi IE. 2012. Unprecedented Ichneumonid parasitoid wasp diversity in tropical forests. Biological Scienses 279:4694-469. doi: https://doi.org/10.1098/rspb.2012.1664.

Wharton RA. 1997. Manual of the new world genera of the family Braconidae (Hymenoptera): introduction. Di dalam: Wharton RA, Marsh PM, Sharkey MJ (Eds.), Manual of the New World Genera of the Family Braconidae (Hymenoptera). hlm. 1-12. Washington: The International Society of Hymenopterist. 